\title{
100 år i kamp
}
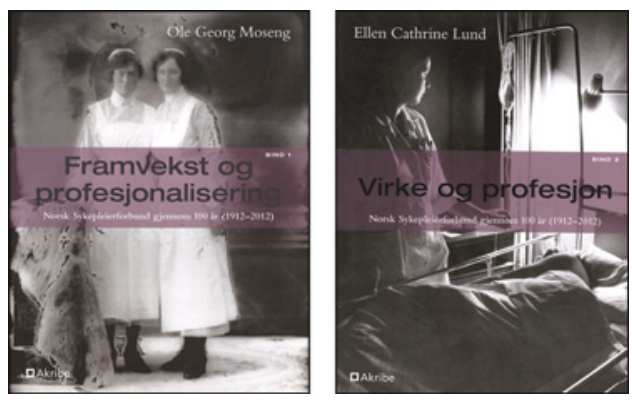

Ole Georg Moseng, Ellen Cathrine Lund

Norsk Sykepleierforbund gjennom 100 år (1912-2012)

2 bd. 1071 s, ill. Oslo: Akribe, 2012.

Pris NOK 990

ISBN 978-82-7950-097-1

Enhver som har ligget på et moderne sykehus, kan bekrefte at det blant sykepleierne finnes utrolig mange engler. Omsorgsfulle sykepleiere er helt avgjørende for at stell og behandling av pasientene skal gå optimalt. Men jammen kan de slåss også! Det går frem av to ruvende bind som Norsk Sykepleierforbund har gitt ut $\mathrm{i}$ anledning hundreårsjubileet sitt i 2012. De er skrevet av to erfarne helsehistorikere, bind 1, Framvekst og profesjonalisering, av Ole Georg Moseng, og bind 2, Virke og profesjon, av Ellen Cathrine Lund.

Sykepleieryrket har vært, og er fortsatt, totalt dominert av kvinner. Tidligere het det derfor Norsk Sykepleierskeforbund. Allerede i 1907 var det stiftet lokale sykepleierskeforeninger i Bergen og Kristiania, og i Bergen startet de samme år opp med en treårig kommunal sykepleieskole. Selve stiftelsen av Sykepleierforbundet skjedde ved at 44 sentrale sykepleiere under ledelse av Bergljot Larsson tok et initiativ i Kristiania. Siden sendte en gruppe av dem ut et opprop med invitasjon til å melde seg inn. Stiftelsen var initiert av en elite som siden fikk bred tilslutning, og Bergljot Larsson var en kraftfull leder i en rekke år.

Sykepleierne i Norge er i dag en skare på 100000 hardt arbeidende og til dels høyt spesialiserte helsearbeidere, som danner en grunnsolid søyle i helsevesenet. Derfor er det en begivenhet at Sykepleierforbundet har satset så stort på å utgi sin egen historie. Forfatterne har klart å se en lang og kompleks historie i fugleperspektiv og sette den i sammenheng med generell helsehistorie. Samtidig gir bøkene et levende innblikk i yrkesorganiseringen til sykepleierne, hvordan faget har utviklet seg, og hvilke kampsaker de har arbeidet for. Og kamper har de virkelig hatt, dels som myndighetene har provosert, og dels som de selv har startet. Ikke minst har de hatt kamper med andre yrkesgrupper innen helsevesenet. Det problematiske forholdet til legene, de tidlige jordmødrene, hjelpepleierne, separat utdanning av helsesøstre og andre helseprofesjoner blir rullet opp på en spennende og ærlig måte. Her har det så visst ikke vært noen «søndagsskole», og de har hatt sterke og markante ledere. Dessuten har det vært sterke brytninger innad i forbundet, og helt opp til nyere tid har medlemmer som kommer med avvikende oppfatninger, vært truet med eksklusjon. En som ble utsatt for dette, var paradoksalt nok en av de store pionerene innen moderne sykepleieforskning, professor Kari Martinsen.

En sentral arbeidsoppgave har vært å bedre sykepleiernes arbeidsforhold og lønnsvilkår, og de har virkelig oppnådd mye. For 100 år siden hadde sykepleierne nærmest umenneskelige arbeidsforhold. Arbeidsdagen kunne ligge på 13 timer helt fra de begynte som elever, og nattevakter kom i tillegg. Da de ofte måtte bo i internat på arbeidsstedet, ble de sosialt nokså bundet. Sykepleierne levde for kallet, og giftet de seg, måtte de slutte i arbeidet. Alt dette er for lengst historie.
Forbundet har også hatt sterke brytninger i spørsmålene om hva sykepleiefaget sto for. Var det bare et praktisk pleie- og omsorgsfag, eller var det også delvis et teoretisk fag? I hvilken grad skulle sykepleie være integrert med medisin og andre helsefag, slik som treårige utdanninger innen fysioterapi, vernepleie og hjelpepleie? Her valgte forbundet $i$ hovedsak å sette høye gjerder rundt sin egen fagkrets. De ønsket ikke å ha felles grunnutdanning med hjelpepleierne, og i lange perioder ønsket de ikke å ha for stort innslag av medisinske fag. Innen forskning satset de på mer samfunnsvitenskapelige vinklinger. Imidlertid var det en stor begivenhet da sykepleieutdanningen kom opp på høgskolenivå. Sykepleie ble også universitetsfag på 1980-tallet, og det ble mulig å ta doktorgrad og å kvalifisere seg videre til professornivå. Dette ga et stort faglig løft, men samtidig ulmet profesjonsdebatten.

Innen sykehussektoren har kampen om hvem som skulle lede hva, og på hvilket nivå, vært særlig intens. Skulle ledelsen være administrativ eller faglig, og hvem kunne bli leder på toppnivå? Her gir bokverket en spennende og til tider nokså underholdende fremstilling av både debatten og de involverte personene.

Det er mye overlapping mellom tidsepoker, og en del også i stoffet om emner og personer. Bokverket kunne derfor ha vunnet på en strammere redigering. Kapitlene er greie og oversiktlige, og hvert nytt kapittel innledes med en side som gir essensen av innholdet. Der er tallrike fotografier som gir en fin bakgrunn for innholdet. Fremfor alt er mye av teksten utrolig spennende lesing, svært åpent fortalt og med klar problematisering av alle de kontroversielle sakene som rulles opp. Det gir et godt inntrykk.

Det er all grunn til å gratulere Norsk Sykepleierforbund med dette bokverket. Det er første gang utviklingen av sykepleiehistorien og forbundet er skildret i sin fulle bredde. Bokverket viser at Sykepleierforbundet fortsatt har mye å arbeide for. I neste hundreårsepoke unner jeg dem å kunne arbeide mer i fred og mer faglig integrert med andre helseprofesjoner.

Bokverket egner seg nok best for sykepleiere og for lesere innen helsevesenet som har spesiell inngang til eller kontakt med sykepleieryrket. Den vil også være verdifull for helseadministratorer og helsepolitikere. De to bindene er vel verdt prisen.

\section{Ole Didrik Lærum \\ Voss}

